\title{
Growth Arrest and DNA Damage-Inducible Protein GADD45 Alpha
}

National Cancer Institute

\section{Source}

National Cancer Institute. Growth Arrest and DNA Damage-Inducible Protein GADD45

Alpha. NCl Thesaurus. Code C17793.

Growth arrest and DNA damage-inducible protein GADD45 alpha (165 aa, $18 \mathrm{kDa}$ ) is encoded by the human GADD45A gene. This protein is involved in the regulation of mitogenic signaling. 